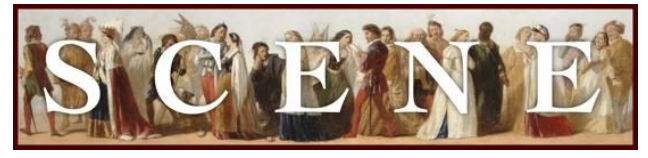

\title{
Depoliticizing Titus in Delhi: The Hungry
}

by Anna Kurian. Written on 2018-01-10. Published in 2017 Issue 2.

For the production: The Hungry (2017, Cinestaan Film Company, India). See production details at the end of the review and at IMDb.com.

IF THE EARLY SHAKESPEAREAN TRAGEDY TITUS ANDRONICUS REVELED IN CARNAGE AND violence, with dismemberment, rape, and cannibalism all serving to make political points regarding gender, race, empire, and power, Bornila Chatterjee's 2017 Indian film adaptation The Hungry relocates the action from ancient Rome to contemporary Delhi and simplifies the cast of characters, paring down the events of the plot while retaining some of the bloody nature of the play. Film adaptations of Shakespeare's plays are not a new phenomenon in India and include the internationally known Bhardwaj trilogy (2003 and after) Maqbool, Omkara, and Haider, as well as lesser known but powerful films such as the late 1990s Malayalam Kaliyattam (based on Othello) and the 1980s Hindi film based on The Comedy of Errors, Angoor. Chatterjee, an independent director whose first film was Let's Be Out, The Sun Is Shining (2012), joins this illustrious line-up with her film based on Titus Andronicus, which is rarely, if ever, produced as theater or film in India. Shakespeare's revenge tragedy is adapted to feature wealthy business families in contemporary India rather than emperors, queens, and generals in Rome, and in the process the deeply political becomes the intensely felt personal. Chatterjee's The Hungry offers a depoliticized Indian English (with a smattering of Hindi) adaptation of Titus Andronicus, keeping the personal center-stage while divesting the text of the politically charged points that it could have made, especially vis a vis gender and class.

Chatterjee strips the plot of many of the Shakespearean elements, eliminating characters altogether or splicing two together so that the cast is nowhere near as large as in Titus. But in the process, she also loses some of the clarity of the storyline. Titus/Tathagat Ahuja, a business tycoon, has only two children: a son, Sunny, and a daughter, Loveleen. This adaptation gives him a wife in a near-vegetative state. The addition of this character is intriguing, as the audience is not allowed to forget her existence: after her rape, Loveleen initially finds refuge in the wife's room; Sunny and Tulsi are taken to her by Tathagat so that she can bless their marriage, and she is the only person who attends the wedding banquet at the end. While Loveleen and Tathagat share an understanding and bond that comforts both, Sunny comes 
across as ineffectual and confused, more a Saturninus figure than a stand-in for Lucius or any of Titus's sons, unable to make sense of the simmering tensions and stresses between his father and the woman he loves, Tamora/Tulsi Joshi. Tulsi's son, Ankur, dies early in the movie, an apparent suicide.

The Joshi and Ahuja families have been closely linked business associates, and Ankur's excitement at being asked to join the business meetings between a politician and the Ahujas is where it all begins: his naiveté leads him to take a video of the bribing of the politician; caught in the act of doing so he is murdered by Tathagat Ahuja's right-hand man, Aaron/Arun Kumar. The suicide note he writes at gunpoint before being killed contains a clue which his brother Chirag and his mother decipher easily enough: it points to Tathagat as his murderer. From there on the cycle of revenge begins as Tulsi plans to "massacre them all," aided by Arun Kumar who is cool, composed, and effortlessly, calmly violent.

But where in the Shakespeare play the extreme violence can be read variously as the cruelty required by the Gods or the violence of a soldier who only knows a battlefield and its ethics, all of it pointing to the lack of a moral core among both the Goths and the Romans, here the multiple layers of Titus are removed, leading to some glaring gaps in the plot and a shaky edifice built thereon. While Tathagat's single-minded devotion to his business empire is the cause of Ankur's death and the impetus which leads to Tulsi wanting to wreak vengeance upon him and his family, the subsequent fallout is almost one-dimensional. Tulsi's desire for vengeance is similar to that of Tamora in Titus Andronicus, but she is unable to effect very much in the process of exacting revenge. The Hungry's representation of gender and gendered violence destabilizes but also reinforces normative gender roles and practices, and the same holds true for its representation of class.

Loveleen's rape by Chirag, Tulsi's second son, happens by accident, with no premeditation, a random act of cruelty fueled by alcohol and overwrought emotion. The rape of Lavinia in Titus Andronicushas been read at multiple levels: as the first strike by Tamora against Titus, as an assertion of power by Tamora in the face of Lavinia's begging, and also as a reinforcement of Tamora's sons' masculinity. It is also the first instance of Aaron's demonstration of his control over classical texts as shaping devices for contemporary events. This densely nuanced sequence in the Shakespearean play is emptied out in The Hungry, as here the rapist is infantilized, and the entire episode happens by chance, with no plotted objective or purpose, Tulsi and Arun getting to know of it after it has happened.

Where the film succeeds is in the harrowing portrayal of Loveleen after the rape, face and body battered almost beyond recognition, her tongue bitten out, arms broken. That she leaves her home and escapes only to return to be murdered by Tulsi further intensifies the chance-based 
nature of Tulsi's revenge, as again there is no premeditation, no plan: Tulsi sees an opportunity and uses it, even as she apologizes to Loveleen for what has happened, what is about to happen. The apology unsettles the viewer as it seems to be not in keeping with Tulsi's plans for vengeance, and yet that infinitesimal moment leads one to hope that Loveleen may be rescued, even as one knows, with complete certainty, that there are no such options in this brutal world. It also humanizes Tulsi, pointing to the difference between Shakespeare's Tamora and Chatterjee's Tulsi, where the former is casually cruel in her dismissal of Lavinia's pleas. Chatterjee's avowed interest in celebrating the "complexity of the woman character" might in part be the reason for this element and the apology, but it also makes the discovery of Loveleen's body that much more shocking ("Director Bornila Chatterjee").

The elimination of the 'honor killing' aspect which Titus privileges is singularly disturbing, as it loses out on an opportunity to comment on a form of violence that is still common in India today. The "pattern, precedent and lively warrant" that Titus invokes as he kills Lavinia is particularly relevant in countries on the Indian subcontinent where rape victims are seen as bringing shame upon the family. Tulsi's killing of Loveleen also simplifies revenge, as leaving her alive, for Tathagat to "behold (her) lively body so," would have been more harrowing as a mode of vengeance. In addition, Tulsi's recurrent attempts to kill Sunny, her bridegroom-tobe, by giving him a doctored recreational drug also appear pointless as Sunny appears unaware of the simmering tensions and animosity between Tulsi and Tathagat. Also, the relationship between Sunny and Tathagat is so thinly sketched that its hard to imagine how Sunny's death would affect Tathagat, unlike the relationship between Loveleen and her father where they understand each other without words. Yet Loveleen's rape and death are incidental and instead Tulsi plans, repeatedly, to eliminate Sunny.

In contrast to Tulsi's floundering attempts at revenge, Tathagat works his way through his plans systematically and with forethought. In sequences such as Arun's entrapment which he effects with minimum fuss and with gentle bonhomie, and his culinary efforts which continue through the last fifteen minutes of the film, Tathagat demonstrates his patriarchal control over the proceedings and the people. If Tulsi and Tathagat's modes of exacting revenge are compared, then the movie reinforces patriarchal power till almost the very end: Tulsi is no kin to Shakespeare's "witty empress" Tamora, who in the Shakespearean text vows to "find a day to massacre them all" and works at doing so "with her sacred wit / To villainy and vengeance consecrate". While desiring vengeance for her son's murder she shows little agency in effecting it, and her vengeance is fortuitous, not intended and pre-planned. The director Bornila Chatterjee said that "we have actually followed the villain (Tamora) from the play and turned her into the heroine Tulsi (Tisca Chopra) in the film" (Khan). Turning her into the heroine seems to 
be connected to making her a more sympathetic character, more appealing to the audience as a wronged mother than as a strong heroine; Tulsi lacks the concentrated strength and singleness of purpose that marks Tamora.

In addition, the introduction of Meena, Tathagat's loyal servant who kills Arun Kumar, further emphasizes the patriarchal control the movie demonstrates, even as its representation of women keeps shifting. Tulsi remains alive as the movie ends, as does Tathagat's wheelchairbound wife, whose unfocussed eyes suddenly focus, shedding a tear in the movie's concluding moments. It is an interesting deviation from Shakespeare's tragedies where usually all the women die, leaving the men in possession of the stage, the victors in a sterile world. Reaching a definite conclusion about the ending remains impossible: Tathagat's wife is wheelchair bound and near vegetative; Tulsi, while she has managed to kill Tathagat, sinks to the floor, broken by the realization of what she has fed on, and in an earlier frame the viewers see Meena standing outside guarding the dining room. Is it then possible to see this as a new beginning or is it an underlining of the emptiness of revenge as the opulent dining room is invaded by an army of goats who take over the room, eating all the greens on the table (akin to the Goths in Titus Andronicus who remain in Rome after helping Lucius to return from exile, in which case it becomes a visual pun)? The invasion of the goats could also be a nod at nature regaining control over the now-destabilized spaces of refined, so-called civilized human interaction, one which we are led up to as the film has a shot of a goatherd with his goats towards the beginning and when Loveleen escapes her father's mansion she crawls towards a landfill, where once again the viewers see goats wandering nearby.

Aaron, the visibly, racially distinct 'other' in Titus Andronicus mirrors Barabas and Ithamore from Marlowe's Jew of Malta and prefigures Iago in his consummate villainy, but in The Hungry class replaces race as the category that renders Arun marginal. While he is, and remains, Tathagat's right-hand man, his passion for Tulsi and his desire for social mobility moves him into her camp. The intensity which Aaron demonstrates after the birth of his baby and his actions to save the baby's life are missing here and the character of Arun remains expressionless and cold. Thus, the part, while played with poise and ease, loses its emotional core. His ambition to become a partner in the business, and thus an equal to the Ahujas and the Joshis, is neither visceral nor searing, and his murder comes as no surprise, quickly and neatly executed by Meena, Tathagat's servant, a potential replacement for Arun Kumar. The near-feudal loyalties and structures of the social world of the film retain their possibilities even as the destabilizing effect of Arun's treachery is temporarily held at bay by Meena's taking of his place.

As the politics of the film remains uncertain, what becomes clear is that, in these new spaces of the rich and the cosmopolitan, the personal is all there is. Questions about lineages and 
inheritances which are crucial to the Shakespearean play are elided and the viewer is left somewhat puzzled at the end. The interrogation of gendered roles in revenge tragedies, a topic that is foregrounded in contemporary productions, is again dealt with in minimal ways, which avoid raising the larger issues of how gender and violence are imbricated in contemporary India. The urgent agency that marks much of Titus Andronicus is also missing as things happen by chance, both death and rape becoming acts that are casual, and random, a matter of being in the wrong place at the wrong time. While the personal remains center-stage, it surprisingly also elides the question of honor, a question that is central to most revenge tragedies, embedded in the politics of whose honor counts, where it is invested, etc. The film is thus depoliticized at multiple levels, including that of the personal.

By setting the film in India, does it then become a postcolonial adaptation? While there are passing nods to the current political scenario in the country, the plot and events are not tethered to explicitly Indian realities, except in very general ways. Thus, Tathagat's anger at the flower seller might be couched in specifically Indian expletives but there is little more than that. Pre-nuptial agreements, children who study in the US or the UK, class and gender distinctions which are uninflected by the nuances of Indian social realities: these go to make up a movie which, though set in a Delhi farmhouse resembling a fort, features characters who are cosmopolitan, inflected by the global rather than the local. In this it represents an aspect of contemporary Indian society with accuracy: the wealthy business classes and their families remain nominally Indian, but their lifestyles and lives are deracinated, apolitical, demonstrating their insertion into a global cultural and social economy. Stylish, starkly beautiful shots of both the principal characters, and two very powerful sequences distinguish Chaterjee's The Hungry, but it simplifies the plot so thoroughly that it leaves no room for a nuanced understanding of character and makes the whole one-dimensional. If the film squanders the opportunity to engage its audience both emotionally and morally, where it does achieve brilliance is in the two sequences which capture the extreme cruelty and ruthlessness of the Shakespearean play: the first is Loveleen's slow crawling escape after she is raped and brutalized, and her inexplicable return, only to be killed by Tulsi. The second is the final sequence: the careful, painstaking preparation of the banquet by Tathagat, and then the visuals of Tulsi and Sunny eating with lip-smacking gusto, all of which is horrifyingly riveting in its excess.

The film makes of Titus Andronicus a flattened terrain, emptied of complexity and density, so can it be that the depoliticization is part of the postcolonial landscape, a new Indian mode of packaging Shakespearean content? Films such as Vishal Bhardwaj's Maqbool, Omkara and Haider have adapted Shakespeare into Hindi, Kaliyattam did 
the same in Malayalam, and these were recognizably local, with language, location, and plot coming together to leave no doubt as to the Indian-ness of the movie, even while they retained their Shakespearean character, in the process achieving both critical and commercial success. If flattening out the complexities and nuances of Shakespeare's plays is a consequence of it being an Indian English film, rather than an Indian language film, then the film raises questions as to why complex density is often the first casualty when we work with canonical English Literature texts in India, whether in English Literature classrooms or when we adapt Shakespeare's plays into English theater or film. These questions occur in the context of many English Literature classrooms in India as well, where often a text is emptied of its complexity and repackaged in simple terms, making it easily accessible but also diminishing its rich potential. Ease of access appears to trump the need to wrestle with difficult questions as in the case of The Hungry. These are questions that are integral to a postcolonial nation such as India as it engages with the legacy of its colonial masters and moves past that legacy to craft its own appropriations thereof.

\section{Works Cited}

"Director Bornila Chatterjee: 'The Hungry' celebrates complexity of women characters." Times of India. $19^{\text {th }}$ October 2017.

Khan, Atif. "Revenge, served cold." The Hindu, 30 ${ }^{\text {th }}$ December 2017.

\section{Production Details}

\section{General}

Title

Year

Production Company

Cast

\begin{tabular}{|c|c|}
\hline TATHAGAT AHUJA & NASEERUDDIN SHAH \\
\hline TUlsi Joshi & TISCA CHOPRA \\
\hline ARUN KUMAR & NEERAJ KaBI \\
\hline CHIRAG JOSHI & ANTONIO AAKEEL \\
\hline LOVELEEN AHUJA & SAYANI GUPTA \\
\hline SUNNY AHUJA & ARJUN GUPTA \\
\hline ANKUR JoshI & SURAJ SHARMA \\
\hline BENTLEY SHARMA & KARAN PANDIT \\
\hline IAID MEENA & SAVITA RANI \\
\hline MR. PODDAAR & JAYANT KRIPALANI \\
\hline
\end{tabular}

The Hungry

2017

Cinestaan Film Company 


\section{Creatives}

$\begin{array}{ll}\text { Director } & \text { Bornila Chatterjee } \\ \text { Music } & \text { Benedict Taylor } \\ \text { Cinematography } & \text { Nick Cooke } \\ \text { Film Editing } & \text { Jamie Kataky } \\ \text { Production Design } & \text { Aradhana Seth } \\ \text { Art Direction } & \text { Devika Dave } \\ \text { Costume Design } & \text { Sheetal Sharma }\end{array}$

